\title{
Herpes simplex virus- 2 infections in pregnant women from South Africa: Evaluation of the ImmunoFLOW rapid test
}

\begin{tabular}{|c|c|}
\hline \multicolumn{2}{|c|}{$\begin{array}{l}\text { Authors: } \\
\text { Shanthie Govender } \\
\text { Lungile Mbambo }^{1} \\
\text { Makandwe Nyirenda }^{2} \\
\text { Motshedisi Sebitloane } \\
\text { Nathlee Abbai }\end{array}$} \\
\hline \multicolumn{2}{|c|}{$\begin{array}{l}\text { Affiliations: } \\
{ }^{1} \text { School of Clinical Medicine } \\
\text { Research Laboratory, Nelson } \\
\text { Mandela School of Medicine, } \\
\text { University of KwaZulu-Natal, } \\
\text { Durban, South Africa }\end{array}$} \\
\hline \multicolumn{2}{|c|}{$\begin{array}{l}{ }^{2} \text { South African Medical } \\
\text { Research Council, HIV } \\
\text { Prevention Research, } \\
\text { Durban, South Africa }\end{array}$} \\
\hline \multicolumn{2}{|c|}{$\begin{array}{l}{ }^{3} \text { Department of Obstetrics } \\
\text { and Gynecology, School of } \\
\text { Clinical Medicine Research } \\
\text { Laboratory, Nelson Mandela } \\
\text { School of Medicine, } \\
\text { University of KwaZulu-Natal, } \\
\text { Durban, South Africa }\end{array}$} \\
\hline \multicolumn{2}{|c|}{$\begin{array}{l}\text { Corresponding author: } \\
\text { Nathlee Abbai, } \\
\text { abbain@ukzn.ac.za }\end{array}$} \\
\hline \multicolumn{2}{|c|}{$\begin{array}{l}\text { Dates: } \\
\text { Received: } 27 \text { June } 2018 \\
\text { Accepted: } 17 \text { Apr. } 2020 \\
\text { Published: } 31 \text { Aug. } 2020\end{array}$} \\
\hline \multicolumn{2}{|c|}{$\begin{array}{l}\text { How to cite this article: } \\
\text { Govender S, Mbambo L, } \\
\text { Nyirenda M, Sebitloane M, } \\
\text { Abbai N. Herpes simplex } \\
\text { virus-2 infections in pregnant } \\
\text { women from South Africa: } \\
\text { Evaluation of the } \\
\text { ImmunoFLOW rapid test. } \\
\text { Afr J Lab Med. 2020;9(1), } \\
\text { a854. https://doi. } \\
\text { org/10.4102/ajlm.v9i1.854 }\end{array}$} \\
\hline \multicolumn{2}{|l|}{ Read online: } \\
\hline 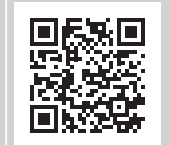 & $\begin{array}{l}\text { Scan this QR } \\
\text { code with your } \\
\text { smart phone or } \\
\text { mobile device } \\
\text { to read online. }\end{array}$ \\
\hline
\end{tabular}

The diagnostic performance of ImmunoFLOW, a rapid test for detecting herpes simplex virus type-2 (HSV-2) infections, was investigated in 248 antenatal women. Approximately one hundred and seventy-seven (71\%) of the enrolled women were infected with HSV-2. Seropositivity was associated with older age ([ $\geq 30$ years] 104/177, 58\%), having a secondary level of education but not tertiary level of education $(125 / 177,70.6 \%)$, and being unmarried $(150 / 177,84.7 \%)$. The sensitivity of the ImmunoFLOW test in relation to the HerpeSelect HSV2 enzyme-linked immunosorbent assay was $89.7 \%$ and specificity was $96.2 \%$. The ImmunoFLOW therefore can serve as a valuable test in screening for HSV-2 infections in pregnant women.

Keywords: HSV-2 infection; pregnant women; rapid test; South Africa.

\section{Introduction}

The South African HIV/AIDS and Sexually Transmitted Infections (STI) Strategic Plan deems the prevention and early treatment of STIs to be a major health priority for the country; emphasis has been placed on the delivery of quality services for testing and treating of STIs. ${ }^{1}$ Simple, rapid and affordable point-of-care tests for diagnosing STIs may be advantageous, because patients can be tested and treatment commenced in a single visit. ${ }^{2}$ Cassette- and strip-based point-of-care tests are highly applicable for use in resource-poor settings, because they do not require electricity, a laboratory or highly trained staff to perform the testing. ${ }^{3}$ Additionally, such tests could have tremendous potential for use in community clinics in an STI-endemic country such as South Africa.

In highly endemic herpes simplex virus type-2 (HSV-2) regions such as South Africa, ${ }^{4,5}$ routine screening for HSV-2 infections would pose a huge financial burden on the health system, because the only available diagnostic tests for HSV-2 are enzyme-linked immunosorbent assays (ELISA), which are expensive and time consuming. Due to the high turn-around time to receive test results, many infected individuals may be lost to follow up. In addition, ELISA requires the use of specialised equipment and highly trained laboratory staff. To address these limitations, rapid point-of-care tests that: are easy to operate, provide results on the same day and are relatively inexpensive would result in a larger number of testing and subsequent treatment infected individuals. The ImmunoFLOW HSV Test (GenBio, San Diego, California, United States) is a point-of-care cassette test that detects IgG to HSV gG-2 (specific HSV type 2 and total HSV [type 1 + type 2]) for type-specific classification, which is not possible using whole virus lysate, and also provides epidemiological information on these diseases. Currently, the diagnostic performance of this test has not been evaluated in a South African setting. Additionally, there is a lack of published research studies on this point-of-care test, both locally and globally.

This study compared the results of the ImmunoFLOW with the HerpeSelect HSV-2 ELISA (Focus Diagnostics, Cypress, California, United States). We used the HerpeSelect HSV-2 ELISA from Focus Diagnostics as our reference test, because this test has been approved by the manufacturer and has a certification mark approval (GmbH, Hannover, Germany) for detection of HSV antibodies in pregnant women globally.

\section{Methods}

\section{Ethical considerations}

The study and all study related materials were approved by the Biomedical Research Ethics Committee, University of KwaZulu-Natal (BE392/17). 


\section{Study setting and population}

The study was conducted between April 2017 and August 2017 at the King Edward VIII Hospital antenatal clinic in Durban, KwaZulu-Natal, South Africa. Two hundred and forty-eight women participated in this study. During screening, an estimated $20 \%$ of the women approached refused study participation. The study criteria included: being pregnant and aged 18 years or older, willing to give written informed consent, willing to undergo a blood draw, and willing to allow the study team to document their HIV status from their clinic cards.

\section{Data and specimen collection}

For this study, data on the women's demographics and clinical information were recorded on a case report form. Women who had symptoms of genital ulcers and sores were treated by syndromic management. For the syndromic management approach, patients presenting with a genital ulcer or sore were treated with aciclovir, oral, $400 \mathrm{mg}$ 8-hourly for 7 days.

Venous blood ( $3.5 \mathrm{~mL}$ ) was collected by a hospital professional nurse. The blood was collected into a serum separator gel tube. The blood was processed and tested at University of KwaZuluNatal, School of Clinical Medicine Research Laboratory.

\section{ImmunoFLOW test}

The samples were tested according to the manufacturer's instructions. Test cassettes were placed on a dry level surface, and $100 \mu \mathrm{L}$ of wash solution was added to the cassette. The patient samples were diluted in sample diluent and thereafter $200 \mu \mathrm{L}$ of the dilution was added to the cassette. A second wash step was conducted before the addition of $100 \mu \mathrm{L}$ of Color $\mathrm{G}$ to the cassette. A final wash step was performed and the results were available within $2 \mathrm{~min}$. Each cassette included a reagent-positive control. The presence of a red or pink dot in the individual test and control windows was read as a positive result.

\section{HerpeSelect HSV-2 enzyme-linked immunosorbent assay}

The HerpeSelect HSV-2 ELISA assay is a glycoprotein G-based type-specific ELISA technique which produces qualitative results. Two hundred ul of each serum sample was tested according to the manufacturer's recommendations (Focus Diagnostics, Cypress California, United States). Controls that were provided with kits were included for all runs: IgG High Positive Control (index value greater than 3.5); IgG Low Positive Control (index value between 1.5-3.5); and Negative Control (index value less than 0.8 ). The cut-off value used to determine a positive result was $>1.10$ index value; $0.9-1.10$ index values were considered equivocal and index values $<0.9$ were considered as negative results. All samples that produced equivocal index values were re-tested.

\section{Data analysis}

All analyses were performed using STATA, version 14 (StataCorp LLC, College Station, Texas, United States).
The diagnostic performance (i.e. sensitivity, specificity, positive predictive value, and negative predictive value) of the ImmunoFLOW test was compared to the gold standard HerpeSelect HSV-2 ELISA. A $p$-value of $<0.05$ was considered as significant.

\section{Results}

A prevalence of 177/248 (71.4\%) for HSV-2 was observed on the ImmunoFLOW test and prevalence was 195/248 (78.6\%) on the HerpeSelect HSV-2 ELISA. The prevalence of HIV in this population was $124 / 248 \quad(50.0 \%)$. Approximately $(107 / 177)$ of the women were positive for HSV-2 and were also HIV-positive. The majority of the women who tested positive for HSV-2 were older than age 30 years (104/177, $58 \%, p=0.001)$, had completed secondary education but not tertiary education $(125 / 177,70.6 \%, p=0.05)$, were unemployed $(107 / 177,60.5 \%, p=0.55)$, were unmarried $(150 / 177,84.7 \%, p=0.02)$ and reported having more than one lifetime sexual partners $(164 / 177,92.6 \%, p=0.0002)$ (Table 1$)$.

The sensitivity of the ImmunoFLOW test was $89.7 \%$ and its specificity was $96.2 \%$. Of the 248 samples tested, 175 samples were correctly classified as positive by the ImmunoFLOW test. However, there were 2 samples that the ImmunoFLOW test classified as positive whereas the reference test classified these as negative. In addition, 20 samples were falsely classified as negative by the ImmunoFLOW (Table 2). The positive predictive value of the ImmunoFLOW was $98.9 \%$ and its negative predictive value was $71.8 \%$. The overall predicitive accuracy of the ImmunoFLOW test was 91.1\% (95\% confidence interval: $86.9 \%-94.4 \%$ ) (Table 3).

\section{Discussion}

The $78.6 \%$ prevalence of HSV-2 reported in this study was found to be higher than other published studies on antenatal women. $6,7,8,9,10$ A high prevalence of HSV-2 was observed in women who had more partners, thereby emphasising the association between increased number of sex partners and risk of contracting STIs. The performance of the ImmunoFLOW was comparable to other published reports on HSV-2 rapid tests, which reported sensitivities and specificities > $90 \%{ }^{11,12,13,14,15}$ Other published studies on HSV-2 rapid tests have not reported on the performance of those tests in the presence of other viral infections, such as HIV, or genital symptoms relating to infection. In this study, the ImmunoFLOW rapid test performance was not shown to be negatively affected by HIV infection. The test yielded a sensitivity of $91.5 \%$ and specificity of $100 \%$ among HIV-positive women. In addition, the test was able to detect infection in women who were presenting with symptoms of genital ulcers or sores. Among women who were symptomatic, the sensitivity of the test was $91 \%$ and its specificity was $97 \%$. This study highlights that having a test such as the ImmunoFLOW test could greatly contribute to early detection and treatment of women with herpes simplex viruses for improved outcomes for pregnant woman and their babies. 
TABLE 1: Description of pregnant women recruited from the antenatal clinic of the King Edward VIII Hospital in Durban, KwaZulu-Natal, South Africa, 2017.

\begin{tabular}{|c|c|c|c|c|c|c|c|}
\hline \multirow[t]{3}{*}{ Variable } & \multicolumn{6}{|c|}{ HSV-2 status by ImmunoFlow } & \multirow[t]{3}{*}{$p$} \\
\hline & \multicolumn{2}{|c|}{ Total } & \multicolumn{2}{|c|}{ Positive } & \multicolumn{2}{|c|}{ Negative } & \\
\hline & $N$ & $\%$ & $N=177$ & $\%(n / N)$ & $N=71$ & $\%(n / N)$ & \\
\hline \multicolumn{8}{|c|}{ Socio-demographic factors } \\
\hline \multicolumn{8}{|l|}{ Age (years) } \\
\hline $18-24$ & 43 & 17.3 & 26 & 14.7 & 17 & 23.9 & \multirow{4}{*}{0.018} \\
\hline $25-29$ & 75 & 30.2 & 47 & 26.6 & 28 & 39.4 & \\
\hline $30-34$ & 60 & 24.2 & 48 & 27.1 & 12 & 16.9 & \\
\hline$\geq 35$ & 70 & 28.2 & 56 & 31.6 & 14 & 19.7 & \\
\hline \multicolumn{8}{|l|}{ Level of education } \\
\hline Primary & 12 & 4.8 & 9 & 5.1 & 3 & 4.2 & \multirow{3}{*}{0.11} \\
\hline Secondary & 162 & 65.3 & 125 & 70.6 & 37 & 52.1 & \\
\hline Tertiary & 74 & 29.8 & 43 & 24.3 & 31 & 43.7 & \\
\hline \multicolumn{8}{|l|}{ Employed } \\
\hline Yes & 101 & 40.7 & 70 & 39.5 & 31 & 43.7 & \multirow{2}{*}{0.551} \\
\hline No & 147 & 59.3 & 107 & 60.5 & 40 & 56.3 & \\
\hline \multicolumn{8}{|l|}{ Married } \\
\hline Yes & 47 & 19.0 & 27 & 15.3 & 20 & 28.2 & \multirow{2}{*}{0.019} \\
\hline No & 201 & 81.0 & 150 & 84.7 & 51 & 71.8 & \\
\hline Behavioural factors & & & & & & & \\
\hline Has regular partner & & & & & & & \\
\hline Yes & 244 & 98.4 & 175 & 98.9 & 69 & 97.2 & \\
\hline No & 4 & 1.6 & 2 & 1.1 & 2 & 2.8 & 0.340 \\
\hline Living with current pa & & & & & & & \\
\hline Yes & 107 & 43.1 & 79 & 44.6 & 28 & 39.4 & \\
\hline No & 137 & 55.2 & 96 & 54.2 & 41 & 57.7 & 0.516 \\
\hline Refused to answer & 4 & 1.6 & 2 & 1.1 & 2 & 2.8 & \\
\hline Age at first sex (years) & & & & & & & \\
\hline$<15$ & 6 & 2.4 & 5 & 2.8 & 1 & 1.4 & \\
\hline $15-19$ & 164 & 66.4 & 118 & 67.0 & 46 & 64.8 & \\
\hline $20-24$ & 65 & 26.3 & 47 & 26.7 & 18 & 25.4 & 0.449 \\
\hline $25-29$ & 9 & 3.6 & 5 & 2.8 & 4 & 5.6 & \\
\hline$\geq 30$ & 3 & 1.2 & 1 & 0.6 & 2 & 2.8 & \\
\hline Lifetime number of se & & & & & & & \\
\hline 1 & 30 & 12.1 & 13 & 7.3 & 17 & 23.9 & \\
\hline $2-4$ & 154 & 62.1 & 115 & 65.0 & 39 & 54.9 & 0.001 \\
\hline$\geq 4$ & 64 & 25.8 & 49 & 27.7 & 15 & 21.1 & \\
\hline Partner has other par & & & & & & & \\
\hline Yes & 66 & 26.6 & 49 & 27.7 & 17 & 23.9 & \\
\hline No & 74 & 29.8 & 51 & 28.8 & 23 & 32.4 & 0.785 \\
\hline Don't know & 108 & 43.5 & 77 & 43.5 & 31 & 43.7 & \\
\hline Condom use during $p$ & & & & & & & \\
\hline Never & 92 & 37.1 & 57 & 32.2 & 35 & 49.3 & \\
\hline Sometimes & 117 & 47.2 & 86 & 48.6 & 31 & 43.7 & 0.011 \\
\hline Always & 39 & 15.7 & 34 & 19.2 & 5 & 7.0 & \\
\hline Clinical/biological fac & & & & & & & \\
\hline Trimester of pregnan & & & & & & & \\
\hline First & 56 & 22.6 & 39 & 22.0 & 17 & 23.9 & \\
\hline Second & 119 & 48.0 & 83 & 46.9 & 36 & 50.7 & 0.671 \\
\hline Third & 73 & 29.4 & 55 & 31.1 & 18 & 25.4 & \\
\hline HIV status (at enrolm & & & & & & & \\
\hline Negative & 122 & 49.2 & 69 & 39.0 & 53 & 74.6 & \\
\hline Positive & 124 & 50.0 & 107 & 60.5 & 17 & 23.9 & 0.000 \\
\hline Refused & 2 & 0.8 & 1 & 0.6 & 1 & 1.4 & \\
\hline Contraceptive used b & & & & & & & \\
\hline None & 85 & 34.3 & 57 & 32.2 & 28 & 39.4 & \\
\hline Condom & 39 & 15.7 & 31 & 17.5 & 8 & 11.3 & \\
\hline Oral & 16 & 6.5 & 11 & 6.2 & 5 & 7.0 & 0.704 \\
\hline Injection & 96 & 38.7 & 69 & 39.0 & 27 & 38.0 & \\
\hline Implant & 12 & 4.8 & 9 & 5.1 & 3 & 4.2 & \\
\hline
\end{tabular}


TABLE 1 (Continues...): Description of pregnant women recruited from the antenatal clinic of the King Edward VIII Hospital in Durban, KwaZulu-Natal, South Africa, 2017.

\begin{tabular}{|c|c|c|c|c|c|c|c|}
\hline \multirow[t]{3}{*}{ Variable } & \multicolumn{6}{|c|}{ HSV-2 status by ImmunoFlow } & \multirow[t]{3}{*}{$p$} \\
\hline & \multicolumn{2}{|c|}{ Total } & \multicolumn{2}{|c|}{ Positive } & \multicolumn{2}{|c|}{ Negative } & \\
\hline & $N$ & $\%$ & $N=177$ & $\%(n / N)$ & $N=71$ & $\%(n / N)$ & \\
\hline \multicolumn{8}{|l|}{ Current symptoms of genital ulcers or sores } \\
\hline Yes & 158 & 63.7 & 118 & 66.7 & 40 & 56.3 & \multirow{2}{*}{0.126} \\
\hline No & 90 & 36.3 & 59 & 33.3 & 31 & 43.7 & \\
\hline \multicolumn{8}{|l|}{ Treated for STI } \\
\hline Yes & 130 & 52.4 & 102 & 57.6 & 28 & 39.4 & \multirow{2}{*}{0.010} \\
\hline No & 118 & 47.6 & 75 & 42.4 & 43 & 60.6 & \\
\hline \multicolumn{8}{|l|}{ STI symptoms } \\
\hline None & 136 & 54.8 & 89 & 50.3 & 47 & 66.2 & \multirow{4}{*}{0.087} \\
\hline Abnormal vaginal discharge or foul-smelling odour & 27 & 10.9 & 19 & 10.7 & 8 & 11.3 & \\
\hline Genital itching, warts or sores & 63 & 25.4 & 52 & 29.4 & 11 & 15.5 & \\
\hline Multiple & 22 & 8.9 & 17 & 9.6 & 5 & 7.0 & \\
\hline
\end{tabular}

STI, sexually transmitted infections; HSV-2, herpes simplex virus type-2.

$\dagger$, The number of participants $(n)$ for age at first sex is 247 due to missing data for one participant.

TABLE 2: ImmunoFLOW rapid test results compared to HerpeSelect 2 enzyme-linked immunosorbent assay results in antenatal women, KwaZulu-Natal, South Africa, 2017.

\begin{tabular}{|c|c|c|c|}
\hline \multirow[t]{2}{*}{ Reported symptoms and other infections } & \multirow[t]{2}{*}{ ImmunoFlow } & \multicolumn{2}{|c|}{ HerpeSelect 2 ELISA } \\
\hline & & Positive & Negative \\
\hline \multirow[t]{2}{*}{ All women in the sample $(\boldsymbol{n}=248)$} & Positive & 175 & 2 \\
\hline & Negative & 20 & 51 \\
\hline \multirow[t]{2}{*}{ No symptoms of genital ulcers or sores $(\boldsymbol{n}=90)$} & Positive & 58 & 1 \\
\hline & Negative & 9 & 22 \\
\hline \multirow[t]{2}{*}{ Symptoms of genital ulcers or sores $(\boldsymbol{n}=158)$} & Positive & 117 & 1 \\
\hline & Negative & 11 & 29 \\
\hline \multirow[t]{2}{*}{ HIV-negative $(\boldsymbol{n}=122)$} & Positive & 67 & 2 \\
\hline & Negative & 9 & 44 \\
\hline \multirow[t]{2}{*}{ HIV-positive $(n=124)$} & Positive & 107 & 0 \\
\hline & Negative & 10 & 7 \\
\hline \multirow[t]{2}{*}{ HIV-negative and no symptoms of genital ulcers or sores $(n=49)$} & Positive & 25 & 1 \\
\hline & Negative & 4 & 19 \\
\hline HIV-negative and symptoms of genital ulcers or sores symptoms $(\boldsymbol{n}=73)$ & Positive & 42 & 1 \\
\hline \multirow[t]{2}{*}{ HIV-positive and no symptoms of genital ulcers or sores $(n=39)$} & Positive & 32 & 0 \\
\hline & Negative & 4 & 3 \\
\hline \multirow[t]{2}{*}{ HIV-positive and reported no symptoms of genital ulcers or sores $(n=85)$} & Positive & 4 & 0 \\
\hline & Negative & 6 & 75 \\
\hline
\end{tabular}

ELISA, enzyme-linked immunosorbent assay.

TABLE 3: Performance of the ImmunoFLOW rapid test compared to the HerpeSelect 2 enzyme-linked immunosorbent assay in antenatal women, KwaZulu-Natal, South Africa, 2017.

\begin{tabular}{|c|c|c|c|c|c|c|c|c|c|c|c|c|}
\hline \multirow[t]{2}{*}{ Statistic } & \multicolumn{3}{|c|}{ All women in the sample } & \multicolumn{3}{|c|}{$\begin{array}{l}\text { Reported symptoms of genital } \\
\text { ulcers/sores }\end{array}$} & \multicolumn{3}{|c|}{ HIV-positive } & \multicolumn{3}{|c|}{$\begin{array}{l}\text { HIV-negative and reported no genita } \\
\text { ulcers/sores symptoms }\end{array}$} \\
\hline & Value $(\%)$ & $95 \% \mathrm{Cl}$ & $n$ & Value (\%) & $95 \% \mathrm{Cl}$ & $n$ & Value (\%) & $95 \% \mathrm{Cl}$ & $n$ & Value (\%) & $95 \% \mathrm{Cl}$ & $n$ \\
\hline Sensitivity & 89.7 & $84.60-93.62$ & - & 91.4 & $85.14-95.63$ & - & 91.5 & $84.84-95.83$ & & 86.2 & $68.34-96.11$ & - \\
\hline Specificity & 96.2 & $87.02-99.54$ & - & 96.7 & 82.78-99.92 & - & 100.0 & 59.04-100.0 & - & 95.0 & $75.13-99.87$ & - \\
\hline Positive predictive value & 98.9 & 95.74-99.71 & - & 99.2 & $94.45-99.88$ & - & 100.0 & - & - & 96.2 & 78.63-99.41 & - \\
\hline Negative predictive value & 71.8 & $62.66-79.49$ & - & 72.5 & $59.88-82.32$ & - & 41.2 & $27.90-55.87$ & - & 82.6 & $65.54-92.23$ & - \\
\hline Number & - & - & - & - & - & 158 & - & - & 124 & - & - & 49 \\
\hline
\end{tabular}

$N=248$.

$\mathrm{Cl}$, confidence interval.

\section{Limitations}

The limitations of the study were as follows: Western blotting could not be performed as a second confirmatory test due to the high cost of the tests. The testing was performed at a research laboratory by medical technicians and is not a reflection of how the test would be performed at a clinic. Medical technicians are more experienced at laboratory procedures and quality checks. If the test had been conducted by a clinic nurse who has no laboratory experience, the results may have been different. This is yet to be confirmed. However, conducting evaluation studies at antenatal clinics will be a future research consideration. The test required the use of serum. With 
slight modifications, such as using blood collected by finger-prick instead of serum, this test could serve as a valuable test in screening for HSV-2 infections. However, this needs to be evaluated.

\section{Conclusion}

Overall, we have shown that the ImmunoFLOW rapid test performed well in relation to the ELISA. Rapid laboratory tests for diagnosis of STIs will directly contribute to United Nations Sustainable Development Goals that focus on improvement in health. ${ }^{16}$

\section{Acknowledgements}

We gratefully acknowledge the contribution of the women who participated in this study.

\section{Competing interests}

The authors declared no potential conflicts of interest with respect to the research, authorship or publication of this article.

\section{Authors' contributions}

N.A. designed and funded the study. M.N. performed all the statistical analysis. S.G. and L.M. performed all the laboratory testing and analysis. M.S. provided clinical assistance. All authors contributed to the writing of the final manuscript.

\section{Sources of support}

We thank the National Research Foundation of South Africa for funding this study.

\section{Data availability statement}

Data sharing is not applicable to this article as no new data were created or analysed in this study.

\section{Disclaimer}

The views and opinions expressed in this article are those of the authors and do not necessarily reflect the official policy or position of any affiliated agency of the authors.

\section{References}

1. Lewis DA, Maruma E. Revision of the national guideline for first-line comprehensive management and control of sexually transmitted infections: What's new and why? South Afr J Epidemiol Infect. 2009;24(2):6-9. https://doi.org/10.1080/1015 8782.2009.11441341

2. Hsieh $\mathrm{Y}-\mathrm{H}$, Hogan $\mathrm{MT}$, Barnes $\mathrm{M}$, et al. Perceptions of an ideal point-of-care test for sexually transmitted infections-A qualitative study of focus group discussions with medical providers. PLoS One. 2010;5(11):e14144. https://doi.org/10.1371/ journal.pone.0014144

3. Tucker JD, Bien $\mathrm{CH}$, Peeling RW. Point-of-care testing for sexually transmitted infections: Recent advances and implications for disease control. Curr Opin Infect Dis. 2013;26(1):73. https://doi.org/10.1097/QCO.0b013e32835c21b0

4. Abbai NS, Wand H, Ramjee G. Socio-demographic and behavioural characteristics associated with HSV-2 sero-prevalence in high risk women in KwaZulu-Natal. BMC Rese Note. 2015;8(1):1. https://doi.org/10.1186/s13104-015-1093-0

5. Kenyon C, Colebunders R, Buve A, Hens N. Partner-concurrency associated with herpes simplex virus 2 infection in young South Africans. Int J STD AIDS. 2013;24(10):804-812. https://doi.org/10.1177/0956462413482810

6. Lima L, Padalecki G, Castro C, Cordeiro J, De Paula V. Seroprevalence of human herpesvirus type 2 in a reference center for pregnant women in Rio de Janeiro, Brazil. VRR. 2017;22:20-21. https://doi.org/10.17525/vrrjournal. v22i1.327

7. Domercant JW, Louis FJ, Hulland E, et al. Seroprevalence of Herpes Simplex Virus type-2 (HSV-2) among pregnant women who participated in a national HIV surveillance activity in Haiti. BMC Infect Dis. 2017;17(1):577. https://doi. surveillance activity in Haiti. B
org/10.1186/s12879-017-2674-4

8. Anjulo AA, Abebe T, Hailemichael F, Mihret A. Seroprevalence and risk factors of herpes simplex virus-2 among pregnant women attending antenatal care at health facilities in Wolaita zone, Ethiopia. Virol J. 2016;13(1):43. https://doi. org/10.1186/s12985-016-0501-y

9. Nakubulwa S, Kaye DK, Bwanga F, Tumwesigye NM, Nakku-Joloba E, Mirembe FM. Incidence and risk factors for herpes simplex virus type 2 seroconversion among pregnant women in Uganda: A prospective study. J Infect Dev Countr. 2016;10(10):1108-1115. https://doi.org/10.3855/jidc.6874

10. Perti T, Nyati M, Gray G, et al. Frequent genital HSV-2 shedding among women during labor in Soweto, South Africa. Infect Dis Obstet Gynecol. 2014;2014:Article ID 258291:8 pages. https://doi.org/10.1155/2014/258291

11. Ashley RL, Eagleton M, Pfeiffer N. Ability of a rapid serology test to detect seroconversion to herpes simplex virus type 2 glycoprotein $\mathrm{G}$ soon after infection. JCM. 1999;37(5):1632-1633. https://doi.org/10.1128/JCM.37.5.1632-1633.1999

12. Wald A, Ashley-Morrow R. Serological testing for Herpes Simplex Virus (HSV)-1 and HSV-2 infection. Clin Infect Dis. 2002;35(2):S173-S182. https://doi org $/ 10.1086 / 342104$

13. Philip SS, Ahrens K, Shayevich C, et al. Evaluation of a new point-of-care serologic assay for herpes simplex virus type 2 infection. Clin Infect Dis. 2008; 47(10):e79-e82. https://doi.org/10.1086/592696

14. Laderman El, Whitworth E, Dumaual E, et al. Rapid, sensitive, and specific lateral-flow immunochromatographic point-of-care device for detection of herpes simplex virus type 2-specific immunoglobulin $\mathrm{G}$ antibodies in serum and whole blood. CVI. 2008;15(1):159-163. https://doi.org/10.1128/ CVI.00218-07

15. Shevlin E, Morrow RA. Comparative performance of the Uni-Gold ${ }^{\mathrm{TM}} \mathrm{HSV}-2$ Rapid: A point-of-care HSV-2 diagnostic test in unselected sera from a reference laboratory. J Clin Virol. 2014;61(3):378-381. https://doi.org/10.1016/j.jcv. 2014.08.012

16. United Nations General Assembly. Sustainable devlopment goals [homepage on the Internet]. 2015 [cited 2018 Jun 27]. Available from: https://www.un.org/ sustainabledevelopment/sustainable-development-goals/ 